\title{
Teacher's Epistemic Beliefs about the Integration of Digital Literacy in the EFL Classroom
}

Syariful Imam Hadi Cahyono, Nur Arifah Drajati, Ngadiso

Master Degree of English Education Department Universitas Sebelas Maret, Surakarta, Indonesia

Email corresponding author: syarifalimam@gmail.com

How to cite this paper: Cahyono, S. I. H., Drajati, N. A., \& Ngadiso, N. (2019). Teacher's Epistemic Beliefs about the Integration of Digital Literacy in the EFL Classroom. International Journal of Language Teaching and Education, 3(2), 8897.https://doi.org/10.22437/ijolte.v3i2.7962

Accepted: November 20, 2019

Published: December 31, 2019

Copyright $\odot 2019$ International Journal of Language Teaching and Education

This work is licensed under the Creative Commons Attribution International License (CC BY 4.0). http://creativecommons.org/licenses by $/ 4.0 /$

(c) (i)

\begin{abstract}
Digital literacy is the skill which highly important to effectively use digital technology and to survive in the digital-rich environment. The study examines two in-service teachers' epistemic beliefs about the integration of digital literacy in the English Foreign Language classroom. The participants of the study are two English teachers in senior high school in Indonesia. The case study research design was used in the study, and qualitative content analysis was used to analyze the data obtained from the participants. The finding of the study revealed that digital literacy was perceived as a basic skill for learning with digital technology, a skill for collaboration and communication, a skill for evaluating information, and skill for reproduction. The study provided more insight to enhance the understanding of in-service teachers' belief about the integration of digital literacy.
\end{abstract}

\section{Subject Areas}

English as a Foreign Language

\section{Keywords}

Digital Literacy, English as a Foreign Language, Teacher's Epistemic Belief

\section{Introduction}

Nowadays, digital technology is an inseparable part of daily life activity (Voogt, Tilya, \& van den Akker, 2009). It consequently requires to empower a variety of technical, cognitive, and sociological skills to perform tasks and problem-solving in the digital environment (Eshet-Alkalai, 2004) so-called digital literacy (Gilster, 1997). "Digital Literacy is the awareness, attitude and ability of individuals to appropriately use digital tools and facilities to identify, access, manage, integrate, evaluate, analyze and synthesize digital resources, construct new knowledge, create media expressions, and communicate with others, in the context of specific life situations, in order to enable constructive social action; and to reflect upon this process" (Martin, 2005 p. 135). 
Digital literacy is the urgently-need skill in 21st-century skills (Binkley, Erstad, Herman, Raizen, Ripley, Miller-Ricci, \& Rumble, 2011), and one of requirement in the future workplace (Davies, Fidler, \& Gorbis, 2011). According to Bawden (2008), Students required digital literacy skills since it provides the student with the ability to utilize software packages and computers, to understand and create digital information, to assemble knowledge from various sources, to learn independently, and as to behave in a digital environment. Students highly require those sets of skills for their future careers. Thus, the integration of digital literacy in education is inevitable, and teachers are at the forefront of the successful integration of digital literacy.

However, various kinds of barriers influence teachers to integrate digital literacy. Ertmer (2005b) divided the barriers into first-order barriers such as resources, institution, subject culture, and assessment and second-order barriers such as teacher attitudes and beliefs. Further, Ertmer (2005a) found that internal barrier factors still become the pivotal barrier to adopt a tool even though there are available external resources. Additionally, Hew and Brush (2007) found that teacher belief is one of the top barriers which influences teacher to integrate a tool for their pedagogical purposes.

A lot of studies were done regarding teacher belief and digital literacy. Jääskelä, Häkkinen \& RaskuPuttonen (2017) conducted a study about teacher beliefs about learning, pedagogy, and the use of technology in higher education. They conducted thematic interviews with 18 various disciplines teachers. Durriyah \& Zuhdi (2018) did a study of the initial perception of EFL student teachers about integrating digital literacy into a teaching unit. Moreover, Sadaf \& Johnson (2017) surveyed teachers' beliefs about the integration of digital literacy in the classroom practice with the 50 participants from various disciplines such as various subjects, including math, social studies technology, science, computer science, and English.

However, the study of teacher's epistemic beliefs about the integration of digital literacy in the EFL classroom is still limited. Thus, the researcher study about what teacher's epistemic beliefs about the integration of digital literacy in the EFL classroom. The study is expected to contribute to the understanding of the EFL teacher's epistemic beliefs about the integration of digital literacy, particularly in the teaching English field.

\section{Literature review}

According to Kagan, (1992), teacher beliefs are "tacit, often unconsciously held assumptions about students, classrooms, and the academic material to be taught" (p. 65). Further, Kagan (1992) explained that teacher beliefs influence teacher practice more than teacher knowledge. Thus, the teacher's decision on the priorities of teaching arrangement, methods used, and tool selected is influenced by the teacher's belief (Ertmer, 2005b). Sadaf \& Johnson (2017) also found that teacher's belief influenced the intention of teachers to integrate digital literacy.

Furthermore, the perspectives of teacher-centeredness and learner-centeredness were used to 
analyze beliefs about learning and teaching (Liu, 2011). Teachers with teacher-centered beliefs frequently used traditional teaching methods (Meirink, Meijer, Verloop, \& Bergen, 2009). In contrast, teachers with learner-centered beliefs selected methods that support the student to be responsible for their learning (Norton, Richardson, Hartley, Newstead, \& Mayes, 2005). For instance, integrating technology in the classroom was frequently done by teachers with student-centered beliefs (Cope \&Ward, 2002).

Ertmer, Ottenbreit-Leftwich, Sadik, Sendurur, \& Sendurur (2012) conducted multiple case-study research to examine a critical relationship between teacher beliefs and technology integration practices with 20 teachers as the participants. They found that teachers believed that technology could aid them to deliver material and reinforce the skills of students. Besides that, teachers believed technology could complement or enrich the curriculum. For example, students make videos from what they read. Moreover, the teacher also believed that technology could transform teaching and learning.

Gray, Thomas, \& Lewis, (2010) in their study about the use of educational technology in public schools in the USA. They reported that teachers were allowed students to use the computer in the class. Meanwhile, teachers utilize technology for the sake of instructional and administrative purposes, such as presentations and managing student records. Moreover, Jääskelä, Häkkinen, \& Rasku-Puttonen (2017) conducted a qualitative content analysis of teacher beliefs about learning, pedagogy, and the use of technology with 18 teachers. They found that teachers used digital technology to facilitate learning. In their study, teachers believed that digital technologies were a pivotal tool for self-paced studying, an additional tool for active and interactive learning, a tool designed for the integration and assessment of learning, and a tool for changing the learning culture.

Bond, Marín, Dolch, Bedenlier, \& Zawacki-Richter (2018) surveyed teacher perceptions and usage of digital media. They found that most teachers used the institutional platform to check class enrolments, plan seminar topics, and upload materials. The participants dealing with empowering digital media for learning still focused on promoting teacher-centered. Similarly, Englund, Olofsson, \& Price (2017), in their mixed-method study found that teachers tended to use digital technology to promote teacher-centered. The participant in their study believed that technology was used to transmit the material from teachers to students. For example, instead of explaining the same material, the participants believed that it was better to record it and allowed the students to listen to it.

Tan (2013) found that the integration of digital literacy facilitated students to learn through digital resources such as YouTube and Facebook. While students sought for the information, the teachers believed that the student critically analyses the learning resources. Accordingly, the students shaped their skills and self-assurance to integrate online materials in their learning. Another finding of the study also found that the integration of digital literacy could enhance students' engagement and communication.

Moreover, the more various results were found by Kurniawati, Maolida, \& Anjaniputra (2018). They conducted a study about the praxis of digital literacy in the EFL classroom. They found that teachers used digital literacy to promote both teacher-centered and student-centered. In the teacher-centered 
activity, teachers delivered materials through a laptop computer, Microsoft PowerPoint, and an LCD projector to brainstorm, explain, and give the assignments. Moreover, in student-centered activity, the teacher let the student use an electronic dictionary in their mobile phone and PowerPoint slides to accomplish their assignments.

\section{Methodology}

\subsection{Research Design}

A case study research design was used to examine the teacher's epistemic belief about the integration of digital literacy in the EFL classroom. Data were collected from in-depth interviews and document analysis. The research used three data sources to ensure the trustworthiness of the data about the teacher's epistemic beliefs about the integration of digital literacy. In-depth interviews provided data about teacher's epistemic beliefs. Moreover, observation and document provided data about the classroom practice of the integration of digital literacy.

\subsection{Participants}

A purposeful sampling strategy was used to select the participants (Patton, 2002). The participants were selected based on several criteria as follows: (1) in-service English teacher with experience above 5 years, (2) frequently integrating digital literacy in the classroom, (3) frequently attending professional development courses regarding digital technology or digital literacy. Finally, two participants agreed to take part in the research. Both are female and have more than 10 years of teaching experience in the senior high school.

\subsection{Data collection}

The researcher interviewed two teachers to provide insights about their epistemic beliefs about the integration of digital literacy. Interviews were conducted over 3 months, lasted 40-50 minutes each, were recorded, and transcribed. For instance, teachers were asked, "What do you think about how digital literacy should be used in the classroom?" The follow-up questioned were asked via telephone to discover more detail information. Moreover, documents obtained from teachers were also analyses to enrich and support data collected from the interview.

\subsection{Trustworthiness}

In this study, it was used member-check and triangulation to ensure credibility. Member-check was done by giving the interview transcripts each participant to confirm the consistency between the interview transcripts and the interview sessions. Furthermore, in the study, method triangulation was used. According to Carter, Bryant-Lukosius, DiCenso, Blythe, \& Neville (2014), method triangulation involves the use of multiple methods of data collection about the same phenomenon such as interviews, observation, and documentation. Initially, the researcher generated a theme from the interview transcript. The theme was then confirmed in the observation and document analysis. 


\subsection{Data Analysis}

The data from the in-depth interview were analyzed using a constant comparison method (Strauss \& Corbin, 1998). Interview transcripts were read many times to identify a teacher's epistemic beliefs. Tentative labels of data indicating teacher beliefs were created. Similar responses were categorized into a theme. The data obtained from documents were also coded into the existing themes. Categories of data were reanalyzed to answer the research question.

\section{Result}

\subsection{A basic skill for learning with digital technology}

The teacher viewed that digital literacy was useful as a basic skill for learning with digital technology. The teacher used an LCD projector to facilitate students in learning by providing pictures, video or text in which the materials authentic materials. The use of an LCD projector was to provide as many as possible context of the teaching material. Teachers believed that it would shape a holistic understanding of the students between material given in the class and the real-life context.

I frequently used an LCD projector in the class to present learning material that I got from the internet such as video from TEDed. It is more interesting and contextual for the students. (Vita)

Teachers, furthermore, frequently provided students with the video for the sake of brainstorming or supporting material. For brainstorming, teachers believed that it would enhance the visual literacy skill of students. Students decode information and understanding from the visual input which then leads to a more holistic and realistic understanding of the material. The students eventually understand what the purpose of the video creator and what the video creator wanted to communicate.

As the supporting material, teachers believed that by providing video, students learn from more than one mode. It would make a better understanding of the students about the material given. Besides, creating a video also facilitate students to learn speaking skill such as presentation, public speaking, debating which depends on the material. The student could assess and evaluate their speaking themselves before they consult the assignment to teachers.

I asked them to make a video. I think the students could listen, watch, and evaluate their speaking by themselves based on the video that they made before they submit to me. (Vita)

The integration of digital literacy also brings another advantage to the student learning process. The teacher believed that the integration of digital literacy provides opportunities for students to extend their range of sources of information. The students could get a lot of information not only from the teachers and textbooks in the class but also from the internet. Teachers were allowed students to browse in Google, YouTube, wikis, or blogs via the mobile phone to enrich their knowledge.

$I$ allowed them to find other information on the internet. It doesn't matter for me because I believed that there is a lot of knowledge and information out-side there. On the website, YouTube and many more. 
(Tina)

\subsection{A skill for collaboration and communication}

The teacher considered that digital literacy leads the student to communicate with people in and outside of the classroom. Communicating with people in the classroom was done by letting the students interact with their teachers to consult their projects to get feedback. Teachers were allowed their students to ask their tasks via social media such as WhatsApp in the form of MS. Word and submitted their tasks via email after the teachers accepted it.

Furthermore, communicating with the people outside of the classroom was done by letting the student make a video related to the material in which the video would be uploaded to the YouTube channel. Besides learning English by giving explanations and subtitles in English in the video, teachers also believed that the students learn how to communicate digitally to the public. Other teachers ask students to do a photo-voice activity. The students captured interesting things in their environment and shared it with their friends in the class.

The video made by my students was uploaded on YouTube. One of the videos was about the direction of the tourism place. I hope that they can promote those tourism places by using English. (Vita)

\subsection{A skill for evaluating information}

Teachers believed that the students could locate the information that they needed on the internet such as creating relevant keywords to search, finding the relevant text and images, and clicking the right hyperlinks. Moreover, teachers believed that although students were allowed to search the information on the internet, the teacher played a role to guide and discuss the information which the students got from the internet. Teachers, in this case, ensure that the students should learn how to discover the valid information. Teachers believed that it was easier to teach the student to find the relevant information than the valid one.

\subsection{A skill for redesigning}

Teachers believed that by the integration of technology, students would be able to comfortably customize and combine tools that were required by them to achieve their learning goals. For example, when the teachers asked them to make a video, they selected comfortable mobile-application to accomplish the tasks. Of a thousand mobile-application, a student could select the appropriate on to achieve their goal.

When I asked them to make a video, I looked that they used a mobile-app in which I sometimes did not know. Sometimes, my students knew more about what app they could use to accomplish their tasks. Conversely, I still provided a suggestion about what mobile-app they can use. (Tina)

Although it was seemingly a simple task to make a video involve various kinds of digital literacy 
skill. The students initially found the related information in the various kinds of sources such as Website and YouTube, arranged and combined the information in the MS. Word. After taking videos which required visual-multimedia literacy skill, the students then composed the video which required remix literacy. Ultimately, students inserted the subtitle to the video which required information literacy.

\section{Discussion}

The study contributes to improving the understanding and the quality of teaching by integrating digital literacy in the English Foreign Language (EFL) classroom. The result of the study revealed that the teacher uses digital literacy in the EFL classroom to facilitate learning. The teacher believed that digital literacy was highly important for the students since it was a basic skill for learning with digital technology, a skill for collaboration and communication, a skill for evaluating information, and skill for reproduction. The teacher also believed that the integration of digital literacy could enhance the learning process and learning outcome of the students. This finding corroborate a study by (Sadaf \& Johnson, 2017) who found that the integration of digital literacy could facilitate student's learning and preparing students' future careers.

The teacher believed that the integration of digital literacy in the classroom could facilitate students to acquire skills which highly important to learn with digital technology. McDougall, Readman, \& Wilkinson (2018) also found that the integration of digital literacy could enhance the independent learning of the students in the new digital environment. Teachers used an LCD projector to visualize the supporting material in terms of text, pictures, or videos.

Furthermore, teachers believed that besides facilitating students to learn from digital sources such as websites and YouTube, digital literacy shaped a holistic understanding of students. Tan (2013) also found that digital literacy skill facilitate teaching to utilize digital resources which provided students with abundant online learning materials. Further, the integration of digital literacy facilitate students to enhance their skill and self-assurance to select online materials to achieve their learning goal. Those increased students understanding.

Another finding of the study also revealed that teachers believed that digital literacy enhances the collaboration and communication skills of their students. Through the activity such as creating a video, students communicated their ideas to other people. Moreover, the power of social media such as Instagram and YouTube made it possible to communicate their idea to wider audiences. This finding was in line with the study by Comber (2013), cited in Burnett, Merchant, and Parry (2016). The finding of the study revealed that digital literacy provided new opportunities of self-representation and collaboration between the students, their school, families, and communities.

This study also found that the teachers believed the students should be guided to wisely harness the abundant information from the internet since not all of the information was trustful. Students should be responsible for the information that they took from the internet. Accordingly, digital literacy aids students to evaluate information that they obtained. This study corroborate a study from Eshet-Alkalai 
(2004) who reported that information literacy skills could involve the ability of the students to evaluate the quality and validity of information.

In this study, during the learning process, students found the information from various sources including from the internet. They selected the relevant one, reduce and add the additional information. They finally reproduce it in the form of a video. The reproduction skill is a complex literacy skill that students acquired through the integration of digital literacy required multi-dimensional synthetic thinking to create meaningful novice combinations from the old information (Eshet-Alkalai, 2004).

\section{Conclusion}

Based on the study, it is concluded that teachers believe that the integration of digital literacy in the EFL classroom facilitates the student's learning. The teachers believed that the integration of digital literacy benefits students as a basic skill for learning with digital technology, a skill for collaboration and communication, a skill for evaluating information, and skill for reproduction. Furthermore, it is highly important for policy makers and the teachers to provide professional digital development about the integration of digital literacy to support teachers to integrate digital literacy in their classrooms and to enhance the learning process and learning outcome. However, the study has a limited number of participants. The further researcher can conduct a study with the more number of participants.

\section{References}

[1] Bawden, D. (2001). Information and digital literacies: A review of concepts. Journal of Documentation, 57(2), 218-259.

[2] Bawden, D. (2001). Information and digital literacies: A review of concepts. Journal of Documentation, 57(2), 218-259. https://doi.org/10.1108/EUM0000000007083

[3] Binkley, M., Erstad, O., Herman, J., Raizen, S., Ripley, M., Miller-Ricci, M., \& Rumble, M. (2014). Defining twenty-first century skills. In Assessment and teaching of 21st century skills (pp. 17-66). Springer Netherlands. https://doi.org/10.1007/978-94-007-2324-5 2

[4] Bond, M., Marín, V. I., Dolch, C., Bedenlier, S., \& Zawacki-Richter, O. (2018). Digital transformation in German higher education: student and teacher perceptions and usage of digital media. International Journal of Educational Technology in Higher Education, 15(1). https://doi.org/10.1186/s41239-018-0130-1

[5] Burnett, C., G. Merchant, and B. Parry, eds. (2016). Literacy, Media and Technology: Past, Present and Future. London: Bloomsbury.

[6] Carter, N., Bryant-Lukosius, D., Dicenso, A., Blythe, J., \& Neville, A. J. (2014, September 1). The use of triangulation in qualitative research. Oncology Nursing Forum. Oncology Nursing Society. https://doi.org/10.1188/14.ONF.545-547

[7] Cope, C., \& Ward, P. (2002). Integrating learning technology into classrooms: The importance of 
teachers' perceptions. Educational Technology and Society, 5(1), 67-74.

[8] Davies, A., Fidler, D., \& Gorbis, M. (2011). Future Work Skills 2020. University of Phoenix Research Institute (p. 19). Retrieved from http://cdn.theatlantic.com/static/front/docs/sponsored/phoenix/future work skills 2020.pdf

[9] Englund, C., Olofsson, A. D., \& Price, L. (2017). Teaching with technology in higher education: understanding conceptual change and development in practice. Higher Education Research and Development, 36(1), 73-87. https://doi.org/10.1080/07294360.2016.1171300

[10]Ertmer, P. A. (2005a). Teacher pedagogical beliefs: The final frontier in our quest for technology integration? Educational Technology Research and Development. Springer Boston. https://doi.org/10.1007/BF02504683

[11]Ertmer, P. A. (2005b). Teacher pedagogical beliefs: The final frontier in our quest for technology integration? Educational Technology Research and Development. Springer Boston. https://doi.org/10.1007/BF02504683

[12]Ertmer, P. A., Ottenbreit-Leftwich, A. T., Sadik, O., Sendurur, E., \& Sendurur, P. (2012). Teacher beliefs and technology integration practices: A critical relationship. Computers and Education, 59(2), 423-435. https://doi.org/10.1016/j.compedu.2012.02.001

[13]Eshet-Alkalai, Y. (2004). Digital Literacy: A Conceptual Framework for Survival Skills in the Digital era. Journal of Educational Multimedia and Hypermedia.

[14] Gilster, P. (1997). Digital literacy. New York: Wiley.

[15]Gray, L., Thomas, N., Lewis, L., \& Tice, P. (2010). Teachers' use of educational technology in U.S. public schools. Educational Technology (pp. 1-70). https://doi.org/10.1108/09513540910933521

[16]Jääskelä, P., Häkkinen, P., \& Rasku-Puttonen, H. (2017). Teacher Beliefs Regarding Learning, Pedagogy, and the Use of Technology in Higher Education. Journal of Research on Technology in Education, 49(3-4), 198-211. https://doi.org/10.1080/15391523.2017.1343691

[17]Kagan, D. M. (1992). Professional Growth Among Preservice and Beginning Teachers. Review of Educational Research, 62(2), 129-169. https://doi.org/10.3102/00346543062002129

[18] Kurniawati, N., Maolida, E. H., \& Anjaniputra, A. G. (2018). The praxis of digital literacy in the EFL classroom: Digital-immigrant vs digital-native teacher. Indonesian Journal of Applied Linguistics, 8(1), 28-37. https://doi.org/10.17509/ijal.v8i1.11459

[19]Lathipatud Durriyah, T., \& Zuhdi, M. (2018). Digital Literacy With EFL Student Teachers: Exploring Indonesian Student Teachers' Initial Perception About Integrating Digital Technologies Into a Teaching Unit. International Journal of Education and Literacy Studies, 6(3), 53. https://doi.org/10.7575/aiac.ijels.v.6n.3p.53 
[20]Martin, A. (2005). DigEuLit - a European Framework for Digital Literacy: a Progress Report. Journal of ELiteracy, 2, 130-136.

[21]McDougall, J., Readman, M., \& Wilkinson, P. (2018). The uses of (digital) literacy. Learning, Media and Technology, 43(3), 263-279. https://doi.org/10.1080/17439884.2018.1462206

[22] Meirink, J. A., Meijer, P. C., Verloop, N., \& Bergen, T. C. M. (2009). Understanding teacher learning in secondary education: The relations of teacher activities to changed beliefs about teaching and learning. Teaching and Teacher Education, 25(1), 89-100. https://doi.org/10.1016/j.tate.2008.07.003

[23]Norton, L., Richardson, T. E., Hartley, J., Newstead, S., \& Mayes, J. (2005). Teachers' beliefs and intentions concerning teaching in higher education. Higher Education. Kluwer Academic Publishers. https://doi.org/10.1007/s10734-004-6363-z

[24]Patton, M. Q. (2002). Qualitative research and evaluation methods. Qualitative Inquiry (Vol. 3rd, p. 598). https://doi.org/10.2307/330063

[25]Sadaf, A., \& Johnson, B. L. (2017). Teachers' Beliefs About Integrating Digital Literacy Into Classroom Practice: An Investigation Based on the Theory of Planned Behavior. Journal of Digital Learning in Teacher Education, 33(4), 129-137. https://doi.org/10.1080/21532974.2017.1347534

[26]Strauss, \& Corbin, J. (1998). Basics of Qualitative Research: Second Edition: Techniques and Procedures for Developing Grounded Theory. Basics of Qualitative Research Techniques and Procedures for Developing Grounded Theory (Vol. 2nd, p. 336). Sage Publications.

[27]Tan, E. (2013). Informal learning on YouTube: Exploring digital literacy in independent online learning. Learning, Media and Technology, 38(4), 463-477. https://doi.org/10.1080/17439884.2013.783594

[28]Voogt, J., Tilya, F., \& van den Akker, J. (2009). Science teacher learning of MBL-supported studentcentered science education in the context of secondary education in Tanzania. Journal of Science Education and Technology, 18(5), 429-438. https://doi.org/10.1007/s10956-009-9160-8 